\title{
Thermodynamics properties of methane-olefin mixtures under reservoir conditions
}

\section{Vinicius H. Boschini*, Nara A. Policarpo, Nilo R. Kim, Paulo R. Ribeiro}

\section{Abstract}

The work aims to study the properties of the methane-olefin mixture for application well control context. Tests were carried out using a PVT cell and different molar fractions of methane, pressures and temperatures.

\section{Key words:}

Drilling fluids, Methane, Olefin.

\section{Introduction}

The study of the properties of drilling fluids is fundamental for the control of wells during drilling, in order to avoid the occurrence of kicks or even blowouts. Drilling fluids have the role of ensuring the safety of drilling and one of its main functions is to maintain a hydrostatic pressure in the reservoir to ensure that the formation gases do not invade the welli-3. The present work provides studies of the properties of the methane-olefin mixtures for different gas molar fractions performed in a PVT cell under high pressure and high temperature.

\section{Results and Discussion}

The tests were conducted in a PVT cell by the Constant Composition Expansion (CCE) procedure, that consists of the expansion of fluid under constant temperature, through the application of constant pressure gradients. During the test, the pressure, volume, and temperature are recorded ${ }^{2,3}$. The tests were performed with different molar fractions $(y)$ of methane in the mixture $(10,20,30$, and $40 \%$ ), in the temperatures (T) of $20,25,40,60$, and $80^{\circ} \mathrm{C}$, and pressures $(P)$ up to 8000 psi. The tests were run in duplicate and the PVT results recorded were applied in mathematical equations to obtain the mixture properties such as bubble point $\left(P_{\text {sat }}\right)$, specific mass $(\rho)$, solubility $\left(R_{s}\right)$, and oil formation volume factor $\left(B_{\circ}\right)$. The results can be found in Chart 1 and Image 1.

Chart 1. Methane-Olefin mixture properties at saturation.

\begin{tabular}{|l|c|c|c|c|}
\hline $\mathbf{y}(\%)$ & $\mathbf{T}\left({ }^{\circ} \mathbf{C}\right)$ & $\mathbf{P}_{\text {sat }}(\mathbf{p s i})$ & $\mathbf{\rho}\left(\mathbf{g} / \mathbf{c m}^{\mathbf{3}}\right)$ & $\mathbf{B}_{\mathbf{o}}\left(\mathbf{c m}^{\mathbf{3}} \mathbf{\mathbf { c m } ^ { \mathbf { 3 } } \mathbf { s t d } )}\right.$ \\
\hline \multirow{4}{*}{10} & 20 & 1339 & 0,717 & 1,103 \\
\cline { 2 - 5 } & 25 & 1375 & 0,713 & 1,109 \\
\cline { 2 - 5 } & 40 & 1452 & 0,700 & 1,129 \\
\cline { 2 - 5 } & 60 & 1507 & 0,685 & 1,155 \\
\cline { 2 - 5 } & 80 & 1591 & 0,681 & 1,161 \\
\hline \multirow{4}{*}{20} & 20 & 3456 & 0,640 & 1,250 \\
\cline { 2 - 5 } & 25 & 3478 & 0,633 & 1,262 \\
\cline { 2 - 5 } & 40 & 3559 & 0,622 & 1,285 \\
\cline { 2 - 5 } & 60 & 3669 & 0,606 & 1,318 \\
\cline { 2 - 5 } & 80 & 3729 & 0,593 & 1,348 \\
\hline \multirow{4}{*}{30} & 20 & 3487 & 0,645 & 1,256 \\
\cline { 2 - 5 } & 25 & 3522 & 0,641 & 1,265 \\
\cline { 2 - 5 } & 40 & 3601 & 0,630 & 1,286 \\
\cline { 2 - 5 } & 60 & 3693 & 0,616 & 1,317 \\
\cline { 2 - 5 } & 80 & 3805 & 0,599 & 1,353 \\
\hline \multirow{4}{*}{40} & 20 & 5234 & 0,608 & 1,360 \\
\cline { 2 - 5 } & 25 & 5236 & 0,605 & 1,367 \\
\cline { 2 - 5 } & 40 & 5291 & 0,588 & 1,406 \\
\cline { 2 - 5 } & 60 & 5238 & 0,573 & 1,443 \\
\cline { 2 - 5 } & 80 & 5153 & 0,560 & 1,476 \\
\hline
\end{tabular}

1 Thomas, J. E. (Org.). Fundamentos de Engenharia de Petróleo. Rio de Janeiro: Editora Interciência, Petrobras, 2001. 271p.

2 Atolini, T. M. Estudo do comportamento PVT de misturas de metano em emulsões base n-parafina a altas temperaturas, pressões e concentrações de metano. Dissertação, FEM, Unicamp, 2008.

3 Marques, D. C. Estudo das propriedades termodinâmicas de misturas de metano em olefina linear. Dissertação, FEM, Unicamp, 2016. base drilling fluids.

\begin{tabular}{|c|c|c|c|}
\hline $\mathbf{y}(\%)$ & olefin (present work) & olefin $^{3}$ & n-paraffin \\
\hline 10 & 12 & 42 & 48 \\
\hline 20 & 24 & 65 & 144 \\
\hline 30 & 41 & 98 & 149 \\
\hline 40 & 65 & - & 230 \\
\hline
\end{tabular}

It can be concluded that the olefin has an optimal application in the well control, and its performance testifies the usage as a base of drilling fluids.

\section{Acknowledgement}

The authors are thankful for Petrobras financial support and Unicamp for facilities. 